all'uso del Lessico per quanto concerne i sostantivi, gli oggettivi, i verbi, le varianti ed i nomi propri, chiarificando con esempi l'esposizione, e segnala quelle caratteristiche specifiche del criterio seguito nella compilazione delle voci non verbali e verbali. Va sottolineato che la peculiarità in assoluto inedita è quella concordanziale: oltre la traduzione italiana, di ogni termine è offerto l'eventuale rimando alla parola greca, aramaica biblica od ebraica biblica corrispondente, valenza anche questa non indifferente ad un'eventuale applicazione patristica di raffronto tra testi di Patrologia orientale e testi di Patrologia greca o versioni greche della prima, onde ricostruire importanti filoni ermeneutici nella transizione semantica della loro tradizione cristiana.

Fatica non indifferente nella complessità della stesura è quindi pure questa, che accanto alla lodevole competenza professionale di Padre Pazzini vede affiancarsi la passione scientificamente rigorosa dell'amante della Scrittura, in quale in Prefazione dichiara: „Non disponendo di un testo siriaco in formato digitalizzato, lo abbiamo scritto parola per parola e ciò ci ha aiutati a cogliere le sfumature semantiche di ogni singolo lemma".

Siamo pertanto dinanzi ad un'opera il cui alto valore non è attribuibile soltanto alla mente dello studioso, bensì pure in armoniosa intelligenza anche con la sua anima, uscitane stupita di „voce" in „voce" da una sorta di scoperta di „lectio divina" che nell'ultima riga del testo fa tracciare in siriaco all'umile Autore di tanto elevato lavoro: "E' terminato questo scritto, a Dio sia la gloria che non ha fine. AMEN AMEN".

Luciana Maria Mirri - Bologna

\title{
Bogdan CZYŻEWSKI, Księgi Pisma Świętego w ujęciu isagogi Juniliusza Afrykańczyka, Poznań 2003, Wydawnictwo Naukowe UAM, ss. 318.
}

„Jest to niewielkie pismo zawierające teorię biblijnej egzegezy, które można nazwać wprowadzeniem do studiowania i poznania Pisma Świętego" - tak ks. Bogdan Czyżewski charakteryzuje traktat Juniliusza Afrykańczyka, biskupa nieznanej diecezji w Afryce w VI wieku, zatytułowany Instituta regularia divinae legis (w rozprawie pismo to jest najczęściej cytowane jako isagoga, czyli wprowadzenie do studiów biblijnych). Ten niewielki traktat okazuje się ważny i ciekawy, chociaż mało znany. W polskiej literaturze naukowej nie doczekał się dotąd zadnych większych opracowań poza notkami w słownikach czy podręcznikach patrologii. Rozprawa B. Czyżewskiego stanowi więc pierwszą tego rodzaju rozprawę.

Książka omawia fundamentalne kwestie nauczania biblijnego, jakie porusza tekst isagogi: problem kanonu, hermeneutyki i teologii biblijnej, itd. By ukazać jednak oryginalność myśli i ujęć Juniliusza, ks. Czyżewski przedstawia poruszane przez niego zagadnienia w szerszej perspektywie historycznej, bib- 
lijnej i teologicznej, ukazuje ich źródła i umieszcza je w całej tradycji patrystycznej. W ten sposób rozprawa, której temat wydaje się stosunkowo wąski, ukazuje całą panoramę problemów istotnych zarówno dla patrologów, jak też dla biblistów i teologów.

Książka składa się z dwóch części, omawiając dwa zasadnicze aspekty ksiąg Pisma świętego. Pierwszy (ss. 21-122), który ks. Czyżewski nazywał „formalnym", bierze pod uwagę ,stronę zewnętrzną" tych ksiąg (wyrażenie Juniliusza) i dotyczy ich autorów, klasyfikacji, podziału według rodzajów literackich oraz według autorytetu, jaki przydzielała im starożytność chrześcijańska, a przede wszystkim kwestii kanonu biblijnego, która zajmuje najwięcej miejsca w pierwszej części opracowania.

Drugi aspekt ksiąg biblijnych, nazwany „doktrynalnym”, dotyczy treści Pisma świętego. Chociaż isagoga Juniliusza nie stanowi komentarza do poszczególnych wersetów biblijnych, przedstawia jednak interesujący zarys problematyki teologicznej opracowanej na podstawie Starego i Nowego Testamentu. Kwestiom tym poświęcona jest druga cześć rozprawy (ss. 123-290), która ukazuje ważne elementy biblijnej nauki Juniliusza, takie jak: natura Boga, Jego niezmienność i niepojętość, Trójca Święta, chrystologia, nauka o Duchu Świętym, laska i wolna wola czlowieka.

Gruntowna analiza traktatu Juniliusza i odpowiednie podejście metodologiczne pozwoliły ks. Bogdanowi Czyżewskiemu na nowe odczytanie pisma VI wieku, które w dotychczasowych opracowaniach uważano za dzieło niesamodzielne i traktowano jako lacińską adaptację wprowadzenia do Pisma św. autorstwa Pawła Persa, który z kolei miał przedstawiać poglądy Teodora z Mopsuestii i nestorian. Ks. Czyżewski slusznie przeciwstawia się tym poglądom, powtarzanym w wielu opracowaniach. Dowodzi, ze wykaz kanonicznych ksiąg biblijnych, przedstawiony przez Juniliusza jest oryginalny i został sporządzony w oparciu o kryteria stosowane przez św. Augustyna w De doctrina christiana (autor isagogi nie opiera się więc na dziele Pawła Persa). Autor rozprawy trafnie też uzasadnia inną nową tezę głoszącą, że Juniliusz nie reprezentuje poglądów nieortodoksyjnych w chrystologii. Niesłuszne są więc zarzuty wcześniejszych badaczy, zwłaszcza H. Kihna, wskazujące, że Juniliusz zapożyczył błędną chrystologię od Teodora z Mopsuestii i od nestorian. Trafnie ks. Czyzewski podkreśla zależność Juniliusza od św. Augustyna zarówno w kwestiach dotyczących kanonu biblijnego, jak i w zagadnieniach natury doktrynalnej.

Niewątpliwie, rozprawa ta stanowi nowe odczytanie isagogi Juniliusza Afrykańczyka, wydobywa nowe treści i każe zauważyć oryginalność afrykańskiego autora w jego wykladzie Pisma Świętego. Pozwala umieścić Juniliusza w gronie ortodoksyjnych autorów starożytności chrześcijańskiej, którzy pozostawali pod wpływem zachodniej myśli teologicznej, zwlaszcza św. Augustyna. 